\title{
Anthelmintic treatment and supplementation in Nellore calves performance in the post-weaning period
}

\section{Tratamento anti-helmíntico e suplementação no desempenho de bezerros Nelore no período pós-desmame}

\author{
Daniele Floriano Fachiolli1 ${ }^{*}$; Isabela de Lima Saes ${ }^{1}$; João Victor Tino Dellaqua ${ }^{1}$; \\ Osvaldo Alex de Sousa ${ }^{1}$; Leandro Dias Pinto ${ }^{1}$; \\ Pedro Fernando Santi ${ }^{1}$; Paulo Henrique Yamada ${ }^{2}$; Renata Tardivo ${ }^{1}$; \\ Alessandro Francisco Talamini do Amarante ${ }^{3}$; Ricardo Velludo Gomes de Soutello ${ }^{4}$
}

\begin{abstract}
The objective of this study was to analyze the effects of anthelmintic treatment and supplementation of post-weaning Nellore calves. The parasitism degree, hematological changes and animal performance were analyzed, as well as the financial viability. One hundred contemporary Nellore calves were used. Animals were divided into four groups: CS+AT: supplementation with concentrate and anthelmintic treatment; CS: supplementation with concentrate; PS+AT: protein mineral supplementation and anthelmintic treatment; PS: protein mineral supplementation. Coproparasitological, hematological, and cost examinations were performed, and productive performance was also evaluated. A completely randomized design was used. Animals that received CS+AT showed greater weight gain. In females, there was significant difference in egg counts per gram of feces only between the CS and PS+AT. In males, animals receiving CS+AT, CS, and PS+AT differ from those receiving PS. No significant effects were observed for total plasma protein, packed cell volume, and eosinophils count. Females which received PS+AT and males who received CS+AT showed higher profitability. This study concludes that effective anthelmintic use is still viable, with higher profitability when associated with concentrated supplementation in males, and mineral protein supplementation in females. Male calves show better return over investment when compared to females, due to the higher market value and higher potential performance.
\end{abstract}

Key words: Cattle. Stress. Weight gain. Parasitism.

\section{Resumo}

O objetivo do trabalho foi analisar os efeitos do tratamento anti-helmíntico e da suplementação em bezerros da raça Nelore pós-desmame. Foram avaliados o grau de parasitismo, variações hematológicas e desempenho dos animais, bem como a viabilidade financeira. Foram utilizados 100 bezerros contemporâneos da raça Nelore. Os animais foram divididos em quatro grupos: SC+TA: Suplementação com concentrado e tratamento anti-helmíntico; SC: Suplementação com concentrado;

\footnotetext{
${ }^{1}$ Discentes, Universidade Estadual Paulista, UNESP, Faculdade de Ciências Agrárias e Tecnológicas, FCAT, Dracena, SP, Brasil. E-mail: dany_fachiolli@hotmail.com; isa.1.s@hotmail.com; joaovictordellaqua@hotmail.com; osvaldo_souza_13@hotmail. com; leandrodias.zootecnia@hotmail.com; pedrosanti_zootecnia@hotmail.com,reh_tardivo@hotmail.com

${ }^{2}$ Discente, UNESP, Faculdade de Medicina Veterinária e Zootecnia, FMVZ, Distrito de Rubião Júnior, Botucatu, SP, Brasil. E-mail: paulinhoyamada@hotmail.com

3 Prof., UNESP, FMVZ, Distrito de Rubião Júnior, Botucatu, SP, Brasil. E-mail: amarante@ibb.unesp.br

${ }^{4}$ Prof., UNESP, FCAT, Dracena, SP, Brasil. E-mail: soutello@dracena.unesp.br

* Author for correspondence
} 
SP+TA: Suplementação mineral proteica e tratamento anti-helmíntico; SP: Suplementação mineral proteica. Foram realizados exames coproparasitológicos, hematológicos e de custo, o desempenho produtivo também foi avaliado. Foi utilizado o delineamento inteiramente casualizado. Os animais que receberam $\mathrm{SC}+\mathrm{TA}$ apresentaram maior ganho em peso. Nas fêmeas foi observada diferença significativa na contagem de ovos por grama de fezes somente entre os SC e SP+TA. Nos machos, os animais que receberam SC+TA, SC e SP+TA diferiram em relação ao SP. Para proteína plasmática total, volume globular e contagem de eosinófilos não foram observados efeitos significativos. Fêmeas que receberam $\mathrm{SP}+\mathrm{TA}$ e os machos que receberam $\mathrm{SC}+\mathrm{TA}$ apresentaram maior rentabilidade. Conclui-se que o uso de anti-helmíntico eficaz ainda é viável, apresentando maior rentabilidade quando associado à suplementação com concentrado nos machos e suplementação mineral proteica nas fêmeas. Bezerros machos respondem melhor aos investimentos, quando comparado às fêmeas, devido ao maior valor de mercado e maior potencial de desempenho.g

Palavras-chave: Bovinos. Estresse. Ganho de peso. Parasitismo.

\section{Introduction}

Some factors may decrease beef cattle productivity, such as high and low availability and quality of pasture during the seasons of the year, erroneous management, occurrence of parasitic and infectious diseases, mineral deficiencies, etc. (BIANCHIN, 1987). Thus, the factors that negatively influence the production process must be identified, and economically viable alternatives that will bring good results should be researched.

Among the factors that negatively influence the production process, helminths stand out because they are one of the most critical problems of the Brazilian herd, being responsible for major economic losses. In Central Brazil, it is estimated that animals infected with parasites show performance 30 to $70 \mathrm{~kg}$ /year lower than infection-free animals (BIANCHIN, 1996; SOUTELLO et al., 2001). Inefficient control of gastrointestinal nematodes can cause losses of US\$ 6,248 million a year (GRISI et al., 2013).

In Brazil, there is a lack of studies that correlate parasitic and nutritional aspects, especially in postweaning calves raised in conventional grazing system, and few studies in this category of weanling animals. Scientific investigations in this direction are of great value to national fattening in order to make it more efficient.

The objective of this study was to evaluate the effects of anthelmintic treatment, concentrate supplementation, and protein mineral supplementation in male and female Nellore calves in the post-weaning period, analyzing the degree of parasitism, hematological changes and performance. From this, the objective was to perform a cost analysis, making it possible to observe the different treatments' financial viability.

\section{Materials and Methods}

This experiment was submitted to analysis and approved by the Ethics Committee in Animal Use from, State University of São Paulo "Júlio de Mesquita Filho” - Dracena Campus, Brazil (Protocol No. 32/2014).

One hundred contemporary Nellore calves were used, coming from the same lot of matrices, male and female, with average weight of $173.9 \mathrm{~kg}$. They were all weaned on the same day, with approximately eight months of age. The animals were kept in two paddocks formed with Urochloa brizantha grazing, in the city of Castilho/SP, Brazil.

A completely randomized design was used, in which calves were divided into 4 groups of 25 animals each, 13 males and 12 females: CS+AT: supplementation with concentrate and anthelmintic treatment; CS: supplementation with concentrate; PS+AT: protein mineral supplementation and anthelmintic treatment; PS: protein mineral supplementation. To reduce environment effect, the groups were alternated between the two paddocks after each sampling. The experiment was conducted 
in the dry season, starting on June 4, 2014 and ending on October 11,2014; with 129 days in total.

On six occasions, feces samples were collected: on weaning day, a week later, and then every four weeks until the end of 129 days. Egg count per gram of feces was performed (GORDON; WHITLOCK, 1939), fecal culture (ROBERTS; O'SULLIVAN, 1950), and larvae extraction (BAERMANN, 1917).

The identification key described by Keith (1953) was used to identify infective larvae.

Blood collection was performed for hematological analysis at the beginning and end of the experiment. The packed cell volume values (PCV) were determined by the Strumia method (STRUMIA et al., 1954), and expressed as a percentage. Total plasma protein levels (TPP) were estimated by means of a manual handheld refractometer. The reading was performed according to the method of Wolf et al. (1962) and expressed in $\mathrm{g} / \mathrm{L}$. The eosinophil count was performed according to Schalm and Carroll (1986), and expressed in percentage.

Calves were weighed in six periods, concurrently with feces collections, in digital electronic scale to assess the average weight gain. After weighing, animals were relocated to the paddocks with ad libitum water supply.
After the accomplished management, calves remained in the corral during the first night and, after fasting for 12 hours, the application of anthelmintic moxidectin $1 \%$ was performed (Injectable Cydectin ${ }^{\circledR}$ ), administered according to the manufacturer's instructions (Zoetis), only in the treated groups (CS+AT and PS+AT). After eight days of treatment, moxidectin efficacy was verified through EPG percentage reduction (R-EPG). Because moxidectin presented an R-EPG of $73.3 \%$, indicating a possible resistance, albendazole sulfoxide application in the treated animals was performed, reaching then an R-EPG of $93.1 \%$, thus considering this anthelmintic as effective (GMC, 1996, BRASIL, 2012). The administration of anthelmintic albendazole sulfoxide 10\% (Injectable Ricobendazole ${ }^{\circledR}$ ) was performed according to the manufacturer's instruction (Ourofino).

$\mathrm{CS}+\mathrm{AT}$ and CS animals were supplemented with concentrate (CS) of $0.5 \% \mathrm{PCV}$, and PS+AT and PS animals received protein mineral supplementation (PS) with consumption restricted in $0.1 \%$ of PCV, whose composition is presented in table 1 . The adjustment period was five days with CS gradual increase and on the first day animals received 200 gr/animal, with a 200 g/animal increase until reaching the consumption of $1 \mathrm{~kg} / \mathrm{animal} / \mathrm{day}$.

Table 1. Bromatological composition of the supplementation provided to animals after weaning.

\begin{tabular}{ccc}
\hline Nutrients & $\begin{array}{c}\text { CS } \\
(0.5 \% \text { from PCV })\end{array}$ & $\begin{array}{c}\text { PS } \\
(0.1 \% \text { from PCV })\end{array}$ \\
\hline Fibrous Material & $5 \%$ & $4 \%$ \\
Mineral Material & $10 \%$ & $9 \%$ \\
Crude Protein & $18 \%$ & $40 \%$ \\
Ether Extract & $2.5 \%$ & $2.5 \%$ \\
Estimated TDN & $78 \%$ & $38 \%$ \\
\hline
\end{tabular}

Mineral values for concentrate supplementation (CS), and mineral protein supplementation (PS) per product kg, respectively: Calcium: $16.00 \mathrm{~g}$ and $65.00 \mathrm{~g}$, Cobalt: $1.60 \mathrm{mg}$ and $16.00 \mathrm{mg}$, Copper: $24.58 \mathrm{mg}$ and $256.08 \mathrm{mg}$, Sulfur: $270.00 \mathrm{mg}$ and $12.00 \mathrm{~g}$ Iron: $15.00 \mathrm{mg}$ (concentrate supplementation), Fluorine: $180.00 \mathrm{mg}$ (mineral protein supplementation), Phosphorus: $4,500.00 \mathrm{mg}$ and $18.00 \mathrm{~g}$, Iodine: $1.04 \mathrm{mg}$ and $12.40 \mathrm{mg}$, Magnesium: $1,000.00$ and 2,000.00mg, Manganese; $8.96 \mathrm{mg}$ and $83.20 \mathrm{mg}$, Selenium: $0.50 \mathrm{mg}$ and $3.60 \mathrm{mg}$, Sodium $7840.00 \mathrm{mg}$ and $66.00 \mathrm{~g}$, Zinc: $80.64 \mathrm{mg}$ and $806.40 \mathrm{mg}$. 
Cost analysis was calculated according to all expenses computed, using as reference the fixed costs: vaccines (clostridial diseases, foot-and-mouth disease, and brucellosis only in females), pasture, necessary labor and calf price; and variable costs: anthelmintic treatment, concentrate supplementation, and mineral protein supplementation. The intermediate cost (sum of all costs mentioned above) and the final cost (intermediate costs + financial charges $0.5 \%$ per year) were analyzed. The monthly return, the gain in reais $(\mathrm{R} \$)$ per head during the trial period, and the production cost of live kilogram (SOUTELLO, 2001) were calculated from the weight gain and the live calf $\mathrm{kg}$ price (according to male and female prices). The economic analysis was calculated differently, because there were male and female animals and the commercial parameters are different (FURLONG et al., 1993). The data were submitted to variance analysis, and the differences between means were compared by the Tukey test. Statistical analyses were performed using the Minitab Software - Version 17 (MINITAB Inc., 2015).

\section{Results and Discussion}

The analysis of the female calves average daily weight gain (DWG) (Table 2) showed that animals treated with CS+AT or only CS obtained superior performance results compared to animals treated with PS+AT or only PS. As for males (Table 3), DWG difference were observed for groups receiving $\mathrm{CS}+\mathrm{AT}$ or only CS and the group that received PS.

Table 2. EPG and performance of post-weaning female calves which received concentrate supplementation or mineral protein supplementation, with or without anthelmintic application.

\begin{tabular}{|c|c|c|c|c|c|c|}
\hline \multirow[b]{2}{*}{ Variables } & \multicolumn{4}{|c|}{ Groups $^{5}$} & \multirow{2}{*}{$\mathbf{C V}^{4}$} & \multirow{2}{*}{$\mathbf{P}$} \\
\hline & $\mathrm{CS}+\mathrm{AT}$ & CS & $\mathbf{P S}+\mathbf{A T}$ & PS & & \\
\hline Initial weight (kg) & 150.2 & 150.5 & 150.7 & 151.6 & 24.34 & 1.000 \\
\hline Final weight $(\mathrm{kg})$ & 181.4 & 180.6 & 168.3 & 163.5 & 20.64 & 0.556 \\
\hline $\mathrm{WG}^{1}$ average $(\mathrm{Kg})$ & $31.2^{\mathrm{a}}$ & $30.1^{\mathrm{a}}$ & $16.7^{b}$ & $12.8^{\mathrm{b}}$ & 37.69 & $<0.0001$ \\
\hline $\mathrm{DWG}^{2}$ average $(\mathrm{kg} /$ day $)$ & $0.242^{\mathrm{a}}$ & $0.233^{\mathrm{a}}$ & $0.129^{b}$ & $0.099^{\mathrm{b}}$ & 37.74 & $<0.0001$ \\
\hline $\mathrm{EPG}^{3}$ average & 277 ab & $483^{\mathrm{a}}$ & $200^{b}$ & 461 ab & 72.75 & 0.022 \\
\hline
\end{tabular}

Averages with the same letter on the line do not differ $(\mathrm{P}>0.05)$. ${ }^{1} \mathrm{WG}$ : Weight Gain; ${ }^{2} \mathrm{DWG}$ : Daily Weight Gain; ${ }^{3} \mathrm{EPG}$ : Eggs per gram of feces; ${ }^{4} \mathrm{CV}$ : Coefficient of variation. ${ }^{5} \mathrm{Groups}$ : CS+AT: concentrate supplementation and anthelmintic treatment; CS: concentrate supplementation; PS+AT: mineral protein supplementation and anthelmintic treatment; PS: mineral protein supplementation.

Table 3. EPG and performance of post-weaning male calves which received concentrate supplementation or mineral protein supplementation, with or without anthelmintic application.

\begin{tabular}{lcccccc}
\hline \multirow{2}{*}{ Variables } & \multicolumn{9}{c}{ Groups $^{\mathbf{5}}$} & \multirow{2}{*}{ CV $^{4}$} & \multirow{2}{*}{ P } \\
\cline { 2 - 4 } Initial weight $(\mathrm{kg})$ & $\mathbf{C S}+\mathbf{A T}$ & $\mathbf{C S}$ & $\mathbf{P S}+\mathbf{A T}$ & $\mathbf{P S}$ & & \\
Final weight $(\mathrm{kg})$ & 173.1 & 174.8 & 172.8 & 172.0 & 22.74 & 0.988 \\
$\mathrm{WG}^{1}$ average $(\mathrm{Kg})$ & 210.8 & 205.0 & 190.5 & 184.3 & 20.93 & 0.355 \\
$\mathrm{DWG}^{2}$ average $(\mathrm{kg} /$ day) & $37.7^{\mathrm{a}}$ & $30.2^{\mathrm{ab}}$ & $17.8^{\mathrm{bc}}$ & $12.3^{\mathrm{c}}$ & 51.32 & $<0.0001$ \\
$\mathrm{EPG}^{3}$ average & $0.292^{\mathrm{a}}$ & $0.238^{\mathrm{ab}}$ & $0.138^{\mathrm{bc}}$ & $0.095^{\mathrm{c}}$ & 51.10 & $<0.0001$ \\
\hline
\end{tabular}

Averages with the same letter on the line do not differ (P>0.05). ${ }^{1} \mathrm{WG}$ : Weight Gain; ${ }^{2} \mathrm{DWG}$ : Daily Weight Gain; ${ }^{3} \mathrm{EPG}$ : Eggs per gram of feces; ${ }^{4} \mathrm{CV}$ : Coefficient of variation. ${ }^{5} \mathrm{Groups}$ : CS+AT: concentrate supplementation and anthelmintic treatment; CS: concentrate supplementation; PS+AT: mineral protein supplementation and anthelmintic treatment; PS: mineral protein supplementation. 
According to Soutello et al. (2002), comparing the DWG of the group receiving PS+AT to the one of the group receiving only PS, a DWG difference of $0.133 \mathrm{~kg}$ can be seen. This result was superior to the one found in the present study, in which the DWG difference between the group that received protein mineral supplementation and the group that received protein mineral supplementation and anthelmintic treatment was of $0.030 \mathrm{~kg}$ for females, and $0.043 \mathrm{~kg}$ for males. This is probably because this study had a shorter duration and was carried out only in the dry season (129 days after weaning), compared to the study by Soutello et al. (2002), which took place from weaning to slaughter at 24 months of age, with strategic use of anthelmintics for 1.5 years, allowing animals to express higher performance. Furthermore, that study also went through the rainy season, from October to March, when rains are abundant, and probably the pastures quality and availability was higher.

Females who received $\mathrm{CS}+\mathrm{AT}$ gained, on average, $1.1 \mathrm{~kg}$ more than animals that received only CS. Heifers fed with PS+AT gained, on average, 3.9 $\mathrm{kg}$ more than animals that received only PS. The results are in the same data range found by Catto et al. (2005) in which females treated with long-acting anthelmintic have a weight variation from -1.6 to $9.7 \mathrm{~kg}$ (average $6.5 \mathrm{~kg}$ ) more than animals that received no anthelmintic treatment, treated from lactation (3-5 months old) until weaning.

Males who received CS + AT gained, on average, $7.5 \mathrm{~kg}$ more than the animals that received only CS, and the calves receiving PS+AT gained on average $5.5 \mathrm{~kg}$ more than the animals that received only PS. These data are also close to the results found by Catto et al. (2005), in which males treated with long-acting anthelmintic gained from 2.5 to 11.7 $\mathrm{kg}$ (average $6.8 \mathrm{~kg}$ ) more than the control group animals, treated from lactation until weaning.
A significant difference $(\mathrm{P}=0.022)$ in $\mathrm{EPG}$ value was observed for females (Table 2), only among animals receiving $\mathrm{CS}$, and those receiving PS+AT. In males (Table 3), it is clear that animals that received anthelmintic treatment $(\mathrm{CS}+\mathrm{AT}$ and PS+AT) and CS had a lower EPG, compared to the group that received only PS.

For females, there was no significant difference regarding EPG count between the groups that received only $\mathrm{CS}$ and $\mathrm{PS}$, while for males a significant difference could be observed between these groups. The animals receiving CS had a lower EPG when compared to the animals that received PS, and they presented better performance.

There was no significant difference in the initial EPG count (Males: $\mathrm{P}=0.112$; Females: $\mathrm{P}=0.339$ ). EPG reduction in groups treated with anthelmintic compared to untreated groups could be observed after vermifugation in Figures 1 and 2. From the penultimate collection, females do not present significant difference between groups anymore $(\mathrm{P}=$ $0.420)$. Males showed no significant difference $(\mathrm{P}=$ 0.94 ) between treated and untreated groups in the last collection.

Regarding blood tests (Table 4), the packed cell volume average values (PCV), total plasma protein (TPP) and eosinophil count for females and males were not significant $(\mathrm{P}>0.05)$. $\mathrm{PCV}$ values remained within the normal, ranging from 26-49\% (COLES, 1984). Eosinophil count was also kept in the normal range of $0-20 \%$ for eosinophils, according to Lacvet (2015). Normal PPT values range from 67.4 to 74.6 $\mathrm{g} / \mathrm{L}$ (KANEKO et al., 1997). At the beginning of the experiment, the values in most groups were below normal standard, whereas at the end of the experiment all groups presented reduced averages, falling short of the normal standards, but there was no significant difference between groups. 
Figure 1. Egg count mean values per gram of feces of Nellore female calves submitted to four types of treatments from June 4 to October 11, 2014 (Cydectin ${ }^{\circledR}$ application: 06/04/2014, Ricobendazole ${ }^{\circ}$ : 07/15/2014).

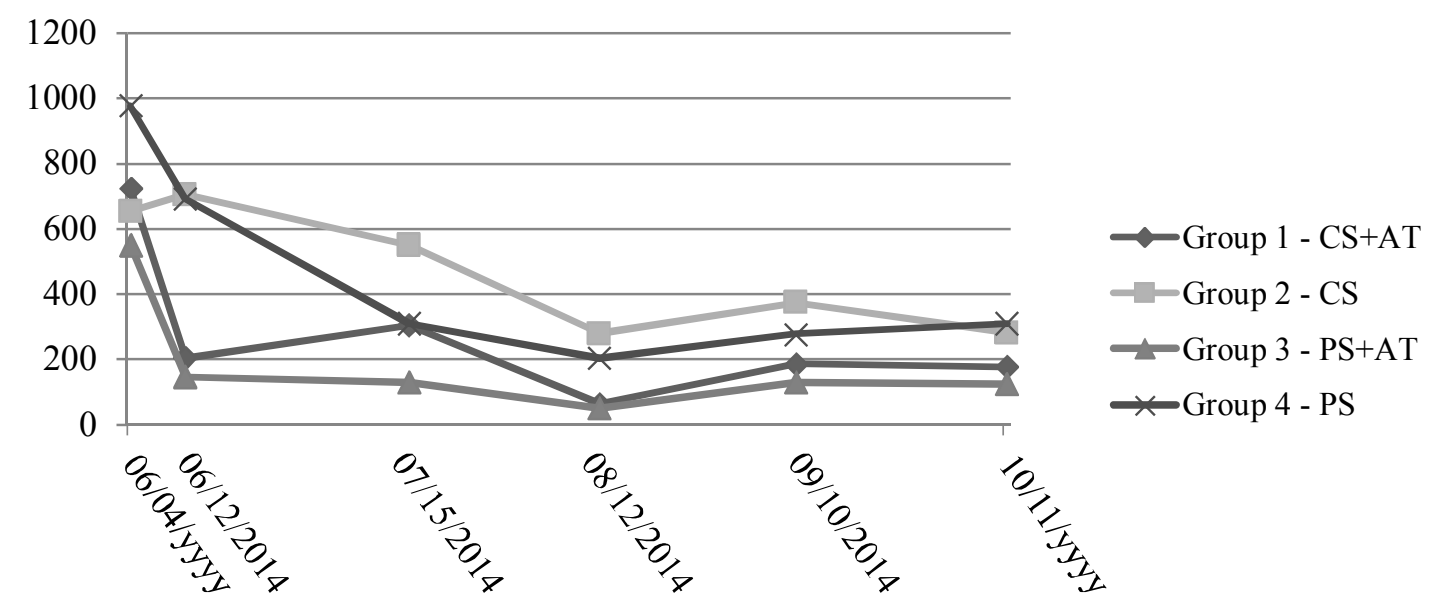

Figure 2. Egg count mean values per gram of feces of Nellore male calves submitted to four types of treatments from June 4 to October 11, 2014 (Cydectin ${ }^{\circledR}$ application: 06/04/2014, Ricobendazole ${ }^{\circledR}:$ 07/15/2014).

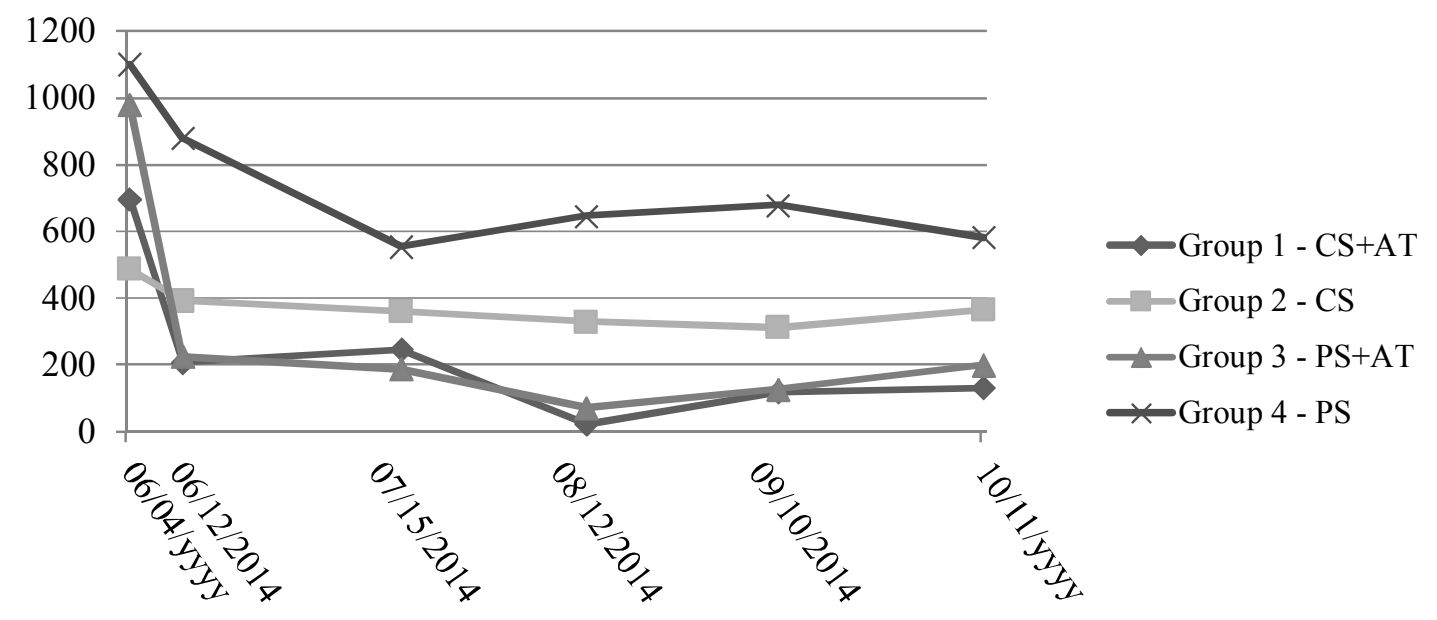

In fecal culture, third instar larvae (L3) were identified and quantified: Haemonchus spp. (56.9\%), Cooperia spp. (29.1\%), Oesophagostomum spp. (7.1\%) and Trichostrongylus spp. (6.9\%) at the beginning of the experiment, analyzing males and females. At the last collection, the proportion of these nematodes was Haemonchus spp. (48.7\%), Cooperia spp. (43.9\%), Oesophagostomum spp. (3.7\%) and Trichostrongylus spp. (3.7\%).
Total operational cost results and profitability indicators for the four treatments are represented in Table 5. Increased profitability can be observed for females who received PS+AT when compared to animals treated with only CS+AT and only CS. Females who received only SP showed the lowest profitability, which agrees with the results obtained by Soutello (2001). This author reported that animals treated with protein supplement and anthelmintic had higher monthly economic profitability than those that received only supplement, or only 
anthelminthic, while the control group animals had the lowest economic profitability. Male animals that received $\mathrm{CS}+\mathrm{AT}$ showed higher profitability, followed by those that received PS+AT, only CS, and only PS.

Table 4. Blood parameters average values: PCV (\%) TPP (g/L), and eosinophils (\%) in females and males after weaning, receiving concentrate supplementation or mineral protein supplementation, with or without anthelmintic application.

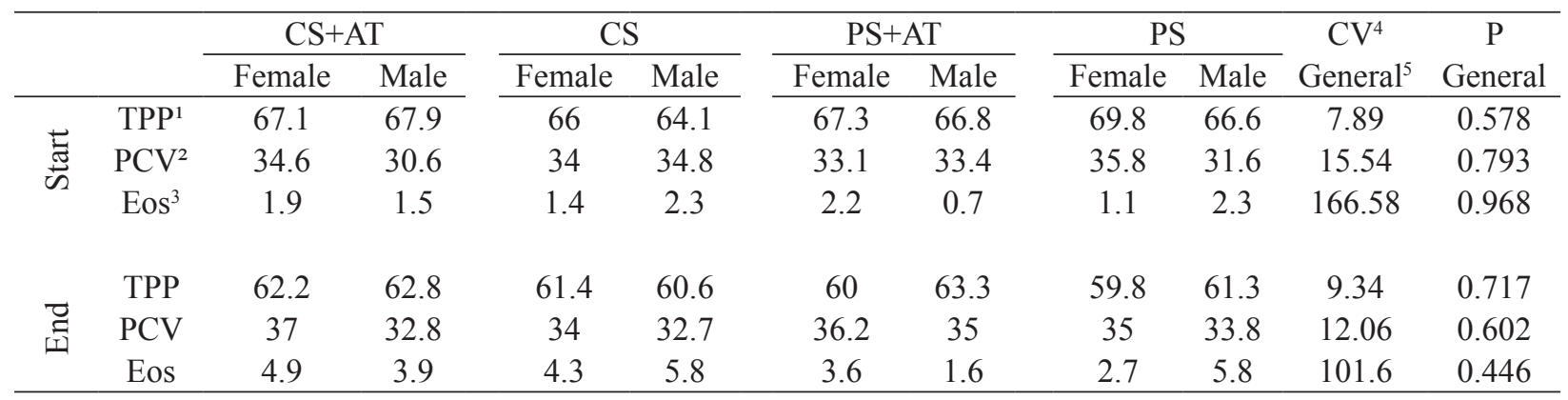

Averages with the same letter on the line do not differ $(\mathrm{P}>0.05) .{ }^{1} \mathrm{TPP}$ : Total plasma protein; ${ }^{2} \mathrm{PCV}$ : Packed cell volume; ${ }^{3}$ Eos: Eosinophils; ${ }^{4} \mathrm{CV}$ : Coefficient of variation. ${ }^{5} \mathrm{Groups}$ (male and female calves): CS+AT: concentrate supplementation and anthelmintic treatment; CS: concentrate supplementation; PS+AT: mineral protein supplementation and anthelmintic treatment; PS: mineral protein supplementation.

The final cost was higher for animals who received $\mathrm{CS}+\mathrm{AT}$, followed by CS, PS + AT and PS in males and females, due to differences in variable costs of anthelmintic and supplementation. However, the produced kilo cost in females that received CS+AT was lower, followed by the CS, PS+AT and PS groups; and in males, the CS+AT group was also lower, followed by the PS+AT, CS and PS groups. Animals that received CS + AT had lower live weight production cost due to greater weight gain, returning the investment with anthelmintic and concentrate supplementation. Analysis of the PS group showed that the kilo production cost is higher due to less weight gain, despite fewer variable costs.
This difference between the kilo production cost between males and females is given by the highest value in the male trade market, where the calf price is higher and, hence, so is the arroba price. This causes males to have a higher selling price (ANUALPEC, 2015). In addition, males are more affected by gastrointestinal helminths compared to females (SEQUEIRA; AMARANTE, 2002), having a larger influence of anthelmintic treatment on performance, thereby making treatment with concentrate supplementation and anthelmintic feasible. 


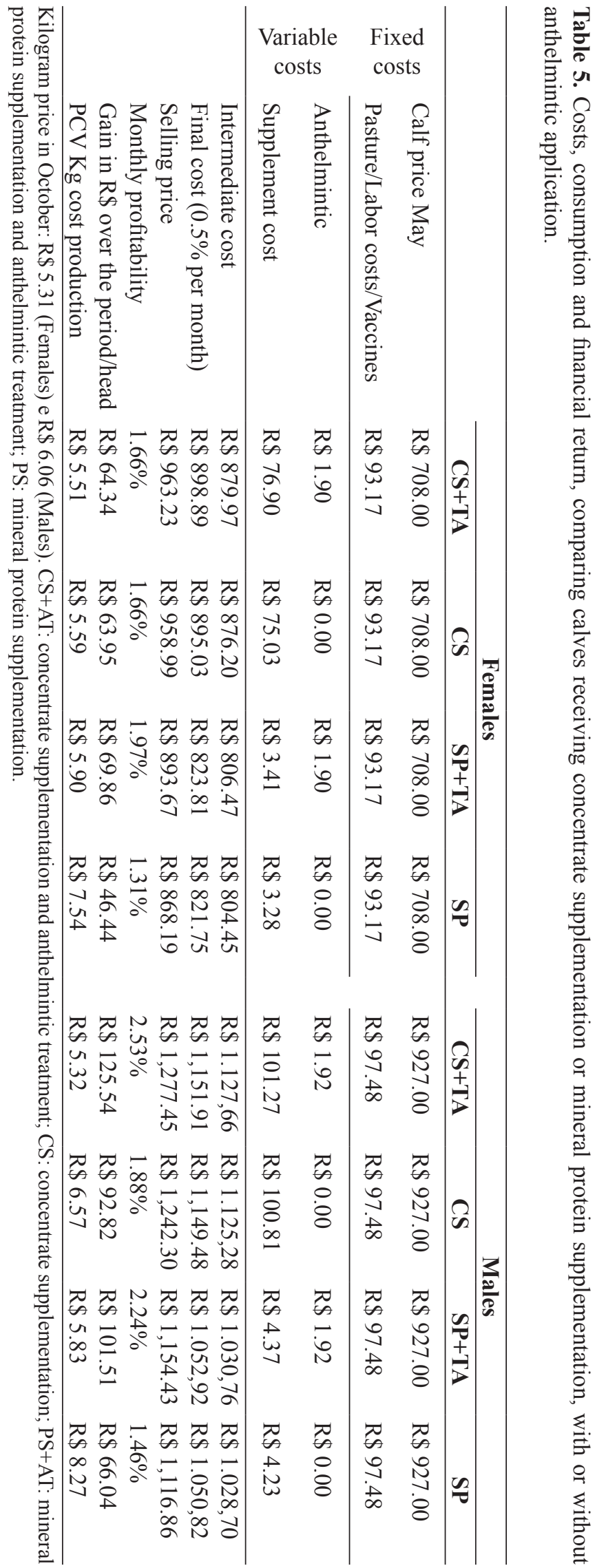

\section{Conclusion}

Concentrate supplementation provides improved nutritional support to calves, hindering gastrointestinal helminths implantation, and increasing performance, whether or not they are treated with anthelmintic. Supplementation and anthelmintic use did not influence on hematological patterns through treatments. However, the use of effective anthelmintic is still economically viable in the post-weaning period, presenting higher profitability associated with concentrate supplementation in males and mineral protein supplementation in females.

\section{Reference}

ANUÁRIO DA PECUÁRIA BRASILEIRA ANUALPEC. Informa Economics FNP -Consultoria e Comércio. São Paulo: FNP, 2015. São Paulo: Informa Economics FNP, 2015. 280 p.

BAERMANN, G. Eine Einfache Methode zur auffindung von Ankylostomum (Nematoden) larven in erdproben. Mededelingen uit het Geneeskundig Laboratorium te Weltevreden. Feestbundel. Batavia: Javasche Boekhandel \& Drukkerij, 1917. p. 41-47.

BIANCHIN, I. Controles estratégicos dos nematódeos gastrintestinais em bovinos de corte no Brasil. A Hora Veterinária, Porto Alegre, v. 7, n. 39, p. 49-53, 1987.

BIANCHIN, I. Epidemiologia dos nematódeos gastrintestinais em bovinos de corte nos cerrados e o controle estratégico no Brasil. In: CONTROLE DOS NEMATÓDEOS GASTROINTESTINAIS DE BOVINOS, 1996, Campo Grande. Anais... Campo Grande: EMBRAPA-CNPGL, 1996. p. 113-156.

BRASIL. Ministério da Agricultura, Pecuária e Abastecimento. Legislação relacionada aos produtos de uso veterinário/Ministério da Agricultura, Pecuária e Abastecimento. Secretaria de Defesa Agropecuária. Brasília: MAPA/ACS, 2012. 401 p. Disponível em: $<$ http://www.agricultura.gov.br/arq_editor/file/Aniamal/ leg_prod_veterinarios_WEB.pdf $>$. Acesso em: 13 set. 2016.

CATTO, J. B.; BIANCHIN, I.; TORRES JUNIOR, R. A. A. Efeitos da everminação de matrizes e de bezerros lactentes em sistema de produção de bovinos de corte na região de Cerrado. Pesquisa Veterinária Brasileira, Seropédica, v. 25, n. 3, p. 188-194, 2005. 
COLES, E. H. Patologia clínica veterinária. 3. ed. São Paulo: Manole, 1984. 566 p.

FURLONG, J. Controle de Carrapato dos bovinos na região sudeste do Brasil. Cadernos Técnicos da Escola de Veterinária UFMG, Belo Horizonte, v. 8, p. 49-61, 1993.

GORDON, H. McL; WHITLOCK, A. V. A new technique for counting nematode eggs in sheep feces. Journal Council Scientific Industry Research Australia, Melbourne, v. 12, n. 1, p. 50-52, 1939.

GRISI, L.; LEITE, R. C.; MARTINS, J. R. S.; BARROS, A. T. M.; CANÇADO, P. H. D.; VILLELA, H. S. Perdas econômicas potenciais devido ao parasitismo em bovinos no Brasil. Revista de Educação Continuada em Medicina Veterinária e Zootecnia, Paraíso, v. 11, n. 3, p. 71-71, 2013.

GRUPO MERCADO COMUM - GMC. Regulamento técnico para registros de produtos antiparasitários de uso veterinário. Decisão $N^{o} 4 / 91$, Resolução $N^{o} 11 / 93$. MERCOSUL, Resolução No 76, 1996. Brasília, 1996. 23 p.

KANEKO, J. J.; HARVEY, J. W.; BRUSS, M. L. Clinical biochemistry of domestic animals. $5^{\text {th }}$ ed. New York: Academic Press, 1997. 932 p.

KEITH, R. K. The differentiation of the infective larvae of some common nematode parasites of cattle. Australian Journal of Zoology, Victoria, v. 1, n. 2, p. 223-235, 1953.

\section{LABORATÓRIO DE ANÁLISES CLINICAS} VETERINÁRIAS - LACVET. Tabela de referência: valores normais. Universidade Federal do Rio Grande do Sul. Porto Alegre, 2015. Disponível em: <http://www. ufrgs.br/lacvet/tabela_referencia.php $>$. Acesso em: 15 out. 2015.

MINITAB STATISTICAL SOFTWARE. Minitab Software Inc. Version 17. Pensilvânia, 2015.
ROBERT, F. H. S.; O'SULLIVAN, P. J. Methods for eggs counts and larval cultures for Strongyles infecting the gastrointestinal tract of cattle. Australian Journal of Agricultural Research, Victoria, v. 1, n. 1, p. 99-192, 1950.

SCHALM, O. W.; CARROL, E. J. Schalm's Veterinary hematology. Lea \& Febiger. $4^{\text {th }}$ ed. Philadelphia: WileyBlackwell, 1986. 1277 p.

SEQUEIRA, T. C. G. O.; AMARANTE, A. F. T. Parasitologia animal: animais de produção. Rio de Janeiro: Editora de Publicações Biomédicas, 2002. 149 p.

SOUTELLO, R. V. G. de. Influência do parasitismo e da suplementação no desenvolvimento ponderal de novilhos mestiços Angus-Nelore e da raça Guzerá. 2001. Dissertação (Mestrado em Zootecnia) - Faculdade de Engenharia. Universidade Estadual Paulista Júlio de Mesquita Filho, Ilha Solteira.

SOUTELLO, R. V. G. de.; GASPARELLI JUNIOR, A.; MENEZES, C. F.; DOURADO, H. F.; LIMA, M. A.; BAIER, M. O. Ação e importância dos anti-helmínticos em relação a produção de ruminantes. Ciências Agrárias e da Saúde, Andradina, v. 1, n. 1, p. 55-59, 2001.

SOUTELlO, R. V. G.; CONDI, G. K.; PAES, F.; FONZAR, J. F. Influência do parasitismo e da suplementação proteica no desenvolvimento ponderal de novilhos mestiços Angus-Nelore e da raça Guzerá. Ciências Agrárias e da Saúde, Andradina, v. 2, n. 1, p. 21-27, 2002.

STRUMIA, M. M.; SAMPLE, A. B.; HART, E. D. An improved microhematocrit method. American. Journal of Clinical Pathology, Chicago, v. 24, n. 9, p. 1016-1024, 1954.

WOLF, A. V.; FULLER, J. B.; GOLDMAN, E. J.; MAHONY, T. D. New refractometric methods for determination of total proteins in serum and in urine. Clinical Chemistry, Baltimore, v. 8, n. 158, n.158, 1962. 
